\title{
Protocol Misinterpreted
}

National Cancer Institute

\section{Source}

National Cancer Institute. Protocol Misinterpreted. NCI Thesaurus. Code C106476.

A protocol was misinterpreted. 